\section{EMBRYRIDDLE}

Aeronautical University

SCHOLARLY COMMONS
Journal of Aviation/Aerospace

Education \& Research

Volume 11

Number 1 JAAER Fall 2001

Article 1

Fall 2001

\title{
A Comparison of the Learning Styles of Aviation and Non-Aviation College Students
}

Tim Brady

bradyt@erau.edu

Alan Stolzer

stolzera@erau.edu

Bradley Muller

mullerb@erau.edu

Debbie Schaum

schaumd@erau.edu

Follow this and additional works at: https://commons.erau.edu/jaaer

\section{Scholarly Commons Citation}

Brady, T., Stolzer, A., Muller, B., \& Schaum, D. (2001). A Comparison of the Learning Styles of Aviation and Non-Aviation College Students. Journal of Aviation/Aerospace Education \& Research, 11(1).

https://doi.org/10.15394/jaaer.2001.1286

This Article is brought to you for free and open access by the Journals at Scholarly Commons. It has been accepted for inclusion in Journal of Aviation/Aerospace Education \& Research by an authorized administrator of Scholarly Commons. For more information, please contact commons@erau.edu. 


\section{A COMPARISON OF THE LEARNING STILES OF AVLATION AND NON-AVITION COLLEGE STUDENTS}

Tim Brady, Alan Stolzer, Bradley Muller, and Debbie Schaum

\section{INTRODUCTION}

In contrast to established educational fields such as mathematics, the discipline of aviation education is relatively young. Despite strong signs that our discipline is maturing (Brady 1991), it is not clear as to the extent to which a larger body of instructional theory can be applied specifically to aviation instruction (Telfer 1993, p. 210) or the broader field of aviation education. A starting point in unraveling this complex question is to better understand the characteristics of aviation students. In recent years a limited number of researchers have begun to address this and related questions (Moore and Telfer 1990; Quilty 1996; Green 1998; and Kanske 2001).

In the current study, we seek to relate the learning characteristics of the student in aviation education to the well-established concepts of andragogy and pedagogy. Knowles (1977a) defined "pedagogy" as the art and science of teaching children, and gives an historical account (Knowles 1977b) of the origins of this mode of educational practice in $7^{\text {th }}$ century European monasteries for the purpose of rapidly training a cadre of young workers to copy teachings from decaying scrolls. This is notable because through subsequent centuries this teaching model has been applied to ever broader and more complex learning situations.

Current literature suggests that the traditional lecture format for college classes is not always effective with today's students when used as the sole means for transmitting information (e.g., Campbell 1997). Traditional lecture formats follow the "pedagogical" teaching model in that they are teacher-centered, and not necessarily influenced by the needs or interests of the students.

An alternative teaching model, "andragogy," was popularized by Knowles (1977a) as the art and science of teaching adults, and embodies principles of active learning and greater learner participation. The concept of andragogy has received considerable critical attention (e.g., Pratt 1993, Pratt 1988, Davenport and Davenport 1985, Yonge 1985, Tennant 1985, Darkenwold 1982, Mckenzie 1979, Mckenzie 1977, Elias 1977). Although several articles discuss the merits of andragogy as applied in diverse fields of education (e.g., Patterson 1995, Hatcher et al 1996, Meyer 1977), Rachal's (1994) review concluded "that the trend of the available empirical literature runs counter to many of the anecdotal claims for andragogy superiority over pedagogical methods." Indeed, recent studies point to the view that combined approaches are effective (Richardson and Birge 1995, Hawkins and Kapelis 1993,
Beder, Beder and Natilino (1988).

A potential explanation may be found in the evolving view that instead of a strict dichotomy, andragogy and pedagogy may be seen as a continuum (Davenport and Davenport 1985, p. 154; Rachal 1983, p. 15; Knowles 1979, pp. 52-53). Delahaye et al (1994, p.192) propose an even more complex orthogonal relationship between andragogy and pedagogy, meaning that the two orientations are not correlated and can both be present to varying degrees in the same student.

The purpose of the current research is to determine the extent to which characteristics of freshman students in a university aviation program align with pedagogical versus andragogical orientations, then to compare results with the orientations of traditional college freshman. Brady (1991, p. 3) hypothesized that while traditional college freshmen 
are more likely to display the pedagogical orientation, aviation students are more likely to display a mixture of andragogical and pedagogical characteristics. The following table describes Brady's hypothesis relative to
Knowles' four constructs in the adult learning (andragogy) model: (1) Self-concept, (2) Experience, (3) Readiness-tolearn and (4) Orientation-to-learning.

Learning Model

\begin{tabular}{|l|l|l|l|l|}
\hline $\begin{array}{l}\text { TYPE OF } \\
\text { LEARNER }\end{array}$ & SELF-CONCEPT & EXPERIENCE & READINESS TO & $\begin{array}{l}\text { ORIENTATION } \\
\text { LEARN }\end{array}$ \\
\hline PEDAGOGY & From Others & Low & Extrinsic & Subject-focused \\
\hline ANDRAGOGY & Within & High & Intrinsic & Problem-focused \\
\hline $\begin{array}{l}\text { AVIATION } \\
\text { STUDENT }\end{array}$ & Within & Low + & Intrinsic & Subject-focused \\
\hline
\end{tabular}

\section{CONSTRUCTS}

This section describes the Knowles' constructs and the methodology by which the research team extrapolated statements from the constructs to design a survey instrument used to differentiate andragogical from pedagogical orientations among both aviation and nonaviation freshmen.

\section{Self-Concept}

Self-concept has to do with goal setting. "Selfdirected learners set their own goals and standards. . ." (Grow, 1991, p. 134.). Many college students, particularly freshmen, fit the pedagogical model in that their selfconcept comes from others such as parents or peers. Adult learners, on the other hand, are self-directed (Knowles, 1977). Generally, they are not seeking the meaning of life, but are moving themselves toward goals they have set for themselves.

It was hypothesized that aviation students, even freshmen, relate more closely to the adult learner than the pedagogical learner in that they have made a life-decision. They have a career goal in mind, although it may be somewhat fuzzy, and have begun on the path toward that goal.

To test this hypothesis, two questions were developed for the questionnaire. The first is, I have already determined my intended profession. This relates to selfdirected characteristic of the adult learner in that the adult learner has a clear view of his/her professional goals. On the other hand, the pedagogical learner may not have made this critical decision.

The second question is, Others see me as self- directed. It was important for the respondent to report his/her perception of how others view him/her. This was gleaned from Knowles' description of adult learners as those who see themselves capable of self-direction and wants others to see him/her the same way (Knowles, 1980, p. 184).

\section{Experience}

In terms of the second construct, experience, it was hypothesized that the freshman aviation student more closely relates to the pedagogical model in that, generally, the freshman aviation student brings a similar level of experience to the college environment as does the "typical" freshman. If there is a small distinction it probably leans somewhat toward the "experience plus" in that the aviation student will have at least visited an airport, touched an airplane, or perhaps had an opportunity to operate the flight controls or help do minor repairs.

To test this hypothesis, two questions were developed. The first is, I see a clear connection between what Ilearn in my classes and my experience in day-to-day life. This was derived from Knowles' description of adult learners as those who plan how they are going to apply their learning to their day-to-day lives. Pedagogical learners, on the other hand, regard experience as something that has happened to them without forecasting its application to the future.

The original question in this construct was, It is important to me to get something out of my classes that I can use in my dany-to-day life. When the questionnaire was pre-tested to a group of 19 freshmen in an aviation program, the test statistic indicated the question was not 
discriminating and was too vague to be useful. The revised question proved to provide a discriminating statistic.

The second question is, I learn better from discussion groups than I do from classroom lectures. According to Knowles, there is a distinct shift in emphasis from the teaching techniques used prevalently in pedagogical situations, the lecture, to a learning forum whereby the shared experiences of the learners is very important. There is a shared responsibility for learning between the teacher and the adult learners. By way of contrast, in the pedagogical model, the teacher teaches and the students learn. The teacher is expected to bear the full responsibility for what happens in the teaching-learning scenario (Knowles, 1980, p. 48.)

The original questionnaire also contained the question, My knowledge about life has been gained primarily through the teachings of others rather than through my own life experiences. In the pre-test of the instrument, this question did not discriminate. The research team decided that the question was too abstract and vague to be of value. Since there were two other questions in the instrument that were designed to test for the experience construct, this question was discarded.

\section{Readiness-to-learn}

The construct, readiness-to-learn, goes toward the motivation of the learner: that is, whether the motivation comes from within or without. In the pedagogical model the readiness-to-learn is extrinsic; that is, someone other than the learner is providing the motive force. The pedagogical learner has not yet developed a strong personal interest in the college process. On the other hand, the andragogical learner's motivation is intrinsic; it comes from within (Knowles, 1977).

The hypothesis of this study is that aviation student has an intrinsic readiness-to-learn. The aviation bug has bitten and the aviation student has drawn a mental picture of him or herself in a life scenario that in some way blends the airplane with the intended profession. The aviation student is energetically pursuing that vision, just as scores of other aviation professionals that preceded $\mathrm{him} / \mathrm{her}$ have. In terms of the learning models, the aviation student is expected to relate to the andragogical one.

To test this hypothesis, two questions were developed. The first is, I am attending college primarily because my parents want me to. The second question is, $I$ depend on others to motivate me to learn. These questions were derived from Knowles' description of adult learners as those who coordinate their learning with the recognition of a need to know. This is an intrinsic process that produces teachable moments, for example, an employee who is moving into management recognizes a need to learn modern management practices and seeks out ways to gain the information. In essence, the adult learner is involved in a learning activity because he/she is motivated to do so. Conversely, the pedagogical learner is more likely to be in a learning situation because someone else has made the learning decision. The student's motivation to learn is extrinsic.

\section{Orientation-to-learning}

The final descriptor, orientation-to-learning, relates to whether the learner is subject centered or problem centered (Knowles, 1977a, p. 39 - 54). Andragogical learners have accumulated wisdom that allows them to relate learning as a means of solving problems that occur in the flow of life. They are pursuing an education as a solution to a problem that has revealed itself through life's experience. Learners in the pedagogical model, however, are subject focused in that their pursuit of education is to complete requirements that others have laid down.

The question, I see my education as a means to accumulate knowledge for the future more than as a means for being effective in solving current problems, was formulated to test the orientation-to-learning construct. Knowles states that adults need the opportunity to apply and try out learning quickly and that learning needs to be problem centered. Pedagogical learners, on the other hand, learn things in school that will have application later in life (Knowles 1980, p. 53).

The hypothesis of this study is that aviation students are more closely related to other "typical freshmen" in the orientation-to-learning construct in that they have not yet lived enough life or accumulated enough wisdom to be problem focused.

\section{RESEARCH}

\section{Methodoloey}

Subjects. Three institutions were selected to participate in this study: Embry-Riddle Aeronautical University - Daytona Beach, Saint Louis University, and Florida State University. To test the hypotheses, two sample groups were needed - aviation students and non-aviation students. The researchers decided to select only freshmen level college students for the study to reduce the potential for bias resulting from life experience. The aviation student sample was drawn from the population of aviation students at Embry-Riddle and Parks College. At Embry-Riddle all freshman students (with the exception of one section which was inadvertently omitted) enrolled in the Aviation Science degree who were attending Aeronautics I, a mandatory class, were tested. The Parks College subjects consisted of all students enrolled in a freshman level, introductory aviation course taken exclusively by students enrolled in one of the college's aviation programs. The non-aviation student sample was drawn from the population of nonaviation students at Saint Louis University and Florida 
State University. Subjects at Saint Louis University were drawn from a freshman level core course taken by all undergraduate students at the university. Two sections of the course were randomly selected from a total of nine sections, and the questionnaire was administered to students in the two sections. At Florida State University, nine sections of a required freshman class in English were randomly selected from a total of 44 sections and administered the questionnaire. These procedures produced a total of 325 aviation and 214 non-aviation freshman subjects.

\section{Demographics}

\begin{tabular}{|c|c|c|c|c|c|c|}
\hline & $\mathrm{N}$ & Age $16-19$ & Age 20-25 & Age $>25$ & Female & Male \\
\hline $\begin{array}{l}\text { Saint Louis University } \\
\text { Aviation }\end{array}$ & 69 & 67 & 2 & 0 & 15 & 54 \\
\hline $\begin{array}{l}\text { Embry-Riddle University } \\
\text { Aviation }\end{array}$ & 256 & 234 & 19 & 3 & 29 & 227 \\
\hline $\begin{array}{l}\text { Florida State University } \\
\text { Non-Aviation }\end{array}$ & 131 & 128 & 2 & 1 & 66 & 65 \\
\hline $\begin{array}{l}\text { Saint Louis University } \\
\text { Non-Aviation }\end{array}$ & 83 & 81 & 2 & 0 & 58 & 25 \\
\hline $\begin{array}{r}\text { Total } \\
\text { Sub- Total Aviation } \\
\text { Sub-Total Non-Aviation }\end{array}$ & $\begin{array}{l}539 \\
325 \\
214\end{array}$ & 510 & 25 & 4 & 168 & 371 \\
\hline & Percentage & 94.6 & 4.6 & 0.8 & 31.1 & 68.9 \\
\hline
\end{tabular}

All of the students in this study were first-year freshmen. Students in this study mirrored enrollments nationally in terms of their age, in that most were in the 1619 age category. The ratio of males to females was approximately two males to one female overall, but in the aviation component, the ratio was closer to six to one. In the non-aviation sample, $58 \%$ were female.

\section{Hypothesis Testing}

Since the samples were drawn from three different institutions of higher education, it was necessary to determine on a question-by-question basis whether or not the samples were from the same populations. Otherwise, melding the two samples would produce inappropriate results. The methodology used was to conduct a t-test between like samples (aviation students from one institution compared to aviation students from the other institution, and the same methodology for non-aviation
Instrument. The instrument used to collect the data was a survey questionnaire developed specifically for this study. The questionnaire was distributed to all subjects in the study during class time, and was collected upon completion for a return rate of at or near $100 \%$. The survey was comprised of two sections. Section A consisted of five questions designed to establish the qualifications to serve as a subject for the study, as well as other demographic information. Section B consisted of seven questions to test the constructs of the study. The Likert scale (range: Strongly Disagree to Strongly Agree) was the response model for all questions in Section B.

students). The t-test examinations indicated that the two samples of aviation students from the two institutions (Saint Louis University and Embry-Riddle Aeronautical University) were from the same populations and could be combined as one sample. The t-test examinations for the non-aviation students indicated that the two samples (Florida State University and Saint Louis University) were from the same population for all but question seven. The strategy to test the hypothesis for question 7 , therefore, was to conduct the $t$-tests using the combined sample of aviation students as one group tested against each of the samples from the two non-aviation institutions plus the combined sample. The results of this methodology are indicated in the table below for question seven.

Null Hypothesis 1. In the self-concept construct, there is no significant difference between the aviation student and the non-aviation student. Survey instrument 
question 1 (I have already determined my intended profession.) and question 3 (Others see me as selfdirected.) were used to test this construct.

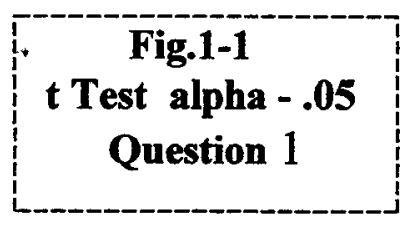

Aviation Students (Freshmen) $\mathbf{n}=325$ Non-Aviation Students (Freshmen) $\mathbf{n}=\mathbf{2 1 4}$

Mean: 4.59

Range of Acceptability

+ or -1.9643 df

537

\author{
Mean: 3.59
}

t Statistic

12.033

\section{Accept or Reject}

Reject

\section{Fig. 1-2}

t Test alpha - .05

Question 3

\begin{tabular}{|c|c|c|c|}
\hline $\begin{array}{l}\text { Aviation Students (Fres } \\
\text { Mean: } 4.08\end{array}$ & $=325$ & $\begin{array}{l}\text { Non-Aviation St } \\
\text { Mean: } 3.86\end{array}$ & en) $n=214$ \\
\hline Range of Acceptability & df & t Statistic & Accept or Reject \\
\hline+ or -1.9643 & 537 & 3.501 & Reject \\
\hline
\end{tabular}

Conclusion: Since the range of acceptability of the $t$-statistic is between -1.9643 and 1.9643 and the t-statistic fell outside that range (12.033 for question 1 and 3.501 for question 3 ), we reject the hypothesis and conclude there is a significant difference between aviation and non-aviation students in the self-concept construct. The means indicate that aviation students relate significantly more to the andragogical model than do the non-aviation students.

Null Hypothesis 2 . In the experience construct, there is no significant difference between the aviation student and the non-aviation student. Survey instrument question 5 (I see a clear connection between what I learn in my classes and my experience in day-to-day life.) and question 7 (I learn more in classroom discussion groups than I do in classroom lectures.) were used to test this construct.

\section{Fig. 1-3 \\ t Test alpha - .05 \\ Question 5 \\ Aviāîiōn Stưđents (Freshmen) n = 325}

Mean: 3.63

Range of Acceptability

+ or -1.9643 df

537
Non-Aviation Students (Freshmen) $\mathbf{n}=\mathbf{2 1 4}$

Mean: 3.05

t Statistic

Accept or Reject

7.219

Reject 


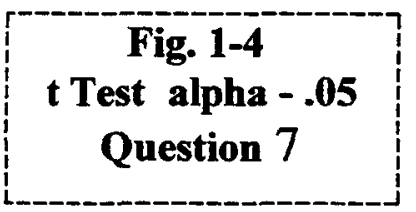

Aviation Students (Freshmen) $\mathbf{n}=325$

Mean: 3.63

Range of Acceptability

+ or -1.965

\section{df}

537

\section{Non-Aviation Students (Freshmen) $\mathrm{n}=\mathbf{2 1 4}$}

Mean: 3.37

$\mathrm{t}$ Statistic

2.82

\section{Accept or Reject}

Reject

Conclusion: Since the range of acceptability of the $t$-statistic is between -1.965 and 1.965 and the $t$-statistic fell outside that range ( 7.219 for question 5 and 2.82 for question 7), we reject the hypothesis and conclude that a significant difference exists between the aviation and the non-aviation student. The means indicate that the aviation student is more closely associated with the adult learner than the pedagogical one.

Null Hypothesis 3 . In the readiness-to-learn construct, there is no significant difference between the aviation student and the non-aviation student. (Survey instrument question 4 ( 1 am attending college primarily because my parents want me to.) and question 6 ( $I$ depend on others to motivate me to learn.) were used to test this construct.

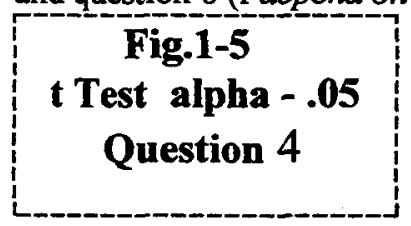

Aviation Students (Freshmen) $\mathbf{n}=\mathbf{3 2 5}$

Mean: 1.55

Range of Acceptability

+ or -1.9643 df

537

\section{Non-Aviation Students (Freshmen) $n=214$}

Mean: 1.68

$\mathrm{t}$ Statistic

1.935
Accept or Reject

Accept

Fig. 1-6
t Test alpha - .05
Question 6

Aviation Students (Freshmen) $\mathbf{n}=325$

Mean: 2.19

Range of Acceptability

+ or -1.9643

\section{df}

537

\author{
Non-Aviation Students (Freshmen) $\mathbf{n}=\mathbf{2 1 4}$ \\ Mean: 2.19 \\ t Statistic

\section{Accept or Reject}

.0269

\section{Accept}

Conclusion: Since the range of acceptability of the t-statistic is between -1.9643 and 1.9643 and the $t$-statistic fell within that range (1.935 for question 4 and 0.269 for question 6), we accept the hypothesis and conclude there is no significant difference between aviation and non-aviation students in the readiness to learn construct. The hypothesis was that the aviation student would relate to the andragogy model and the typical freshman, non-aviation student would relate to the pedagogical model. The means, however, indicate that both aviation and non-aviation student relate more to the andragogical model rather than the pedagogical one. Both student groups are intrinsically motivated to learn.

Null Hypothesis 4 . In the orientation-to-learning construct, there is no significant difference between the aviation student and the non-aviation student. Survey instrument question 2 (I see my education as a means to accumulate knowledge for the future more than as a means for being effective in solving current problems.) was used to test this construct. 
Fig. 1-7

t Test alpha -.05

Question 2

Aviation Students (Freshmen) $n=325 \quad$ Non-Aviation Students (Freshmen) $n=214$

Mean: 4.12

Range of Acceptability

df

Mean: 3.73

+ or -1.9643

537

t Statistic

Accept or Reject

5.16

Reject

Conclusion: Since the range of acceptability of the t-statistic is between -1.9643 and 1.9643 and the $t$-statistic fell outside that range (5.16), we reject the hypothesis and conclude there is a significant difference between aviation and nonaviation students in the self-concept construct.

\section{DISCUSSION}

The findings produced several surprises. It was hypothesized that the aviation student would behave according to the pedagogical model in both the experience and orientation-to-learn constructs and according to the andragogical model in the self-concept and readiness-tolearn constructs. The hypotheses were supported in the selfconcept and readiness-to-learn constructs; however, the research indicated just the opposite for the experience and orientation-to-learn constructs. Here, also, the aviation students relate to the adult model rather than to the pedagogical model as predicted. Interestingly, the research suggests that the aviation student is behaving as an adult learner in all four constructs of Knowles' learning model.
Clearly, then, the aviation student relates to learning as a means of solving problems that occur in the flow of life and like adult learners, need the opportunity to apply and try out learning quickly.

A further surprise in the study was in the readiness-to-learn construct. The learning model predicted that the aviation freshman would exhibit the learning behavior of an adult. This was supported by the research. However, the research also indicated that the non-aviation freshmen relate more to the andragogical model that the pedagogical one. This, too, was the opposite of what the model predicted. The conclusions for each of the constructs are reflected in the modified learning model below.

Modified Learning Model (Differences between hypotheses and findings are shown in bold)

\begin{tabular}{|l|l|l|l|l|}
\hline $\begin{array}{l}\text { TYPE OF } \\
\text { LEARNER }\end{array}$ & SELF-CONCEPT & EXPERIENCE & $\begin{array}{l}\text { READINESS TO } \\
\text { LEARN }\end{array}$ & $\begin{array}{l}\text { ORIENTATION } \\
\text { TO LEARNING }\end{array}$ \\
\hline & From Others & Low & Intrinsic & Subject-focused \\
ANDRAGOGY & Within & High & Intrinsic & Problem-focused \\
\hline AVIATION & Within & High & Intrinsic & Problem-focused \\
\hline STUDENT & & & & \\
\hline
\end{tabular}




\section{LIMITATIONS OF THE STUDY}

A limitation of the current study was the sample size selected for the study. Although nearly all of the freshman aviation students at Embry-Riddle and Parks College were surveyed, this produced only 325 aviation students. It might be argued that this sample size is too small to draw generalized conclusions. According to University Aviation Association (UAA) data, there are approximately 18,000 students enrolled in aviation programs at four-year institutions (UAA, 1999). This equates to approximately 4,500 freshmen students, and yields about a $7 \%$ aviation student sample size. Normal sample size determination would place the minimum sample size at 354 . More significantly, the non-aviation student sample size was only 214 freshmen students drawn from populations at Saint Louis University and Florida State University. A sample size of 400 using normal sample determination would have leant more robustness to the study. The authors acknowledge this limitation, and stress that the results of this study should only be used as preliminary findings.

A second limitation was the number of questions on the survey instrument. For three of the four constructs, two questions were used; for one construct a single question was used, for a total of seven questions. The authors assert that the questions that were developed adequately explored the premise of the constructs, however, future researchers may wish to increase the number of questions on the survey instrument.

A final limitation was the selection of the sample groups. As noted earlier, the aviation sample groups were taken from Embry-Riddle University and Parks College. A broader sampling would have included a random sample made up of potential subjects from all institutions that offer aviation programs. It is also possible that some biases may have been introduced by this limitation in that the institutions used for the aviation student subjects are both private institutions. The same argument can be made of the non-aviation student sample in that random samples were taken from only two institutions, Florida State University and Saint Louis University.

\section{IMPLICATIONS FOR TEACHING THE} COLLEGIATE AVIATION STUDENT

Insofar as the limitations of the current study permit applying the research conclusions, the results of the study seem to confirm the intuitive and long-held observations of aviation educators throughout the world of collegiate aviation education, namely that students engaged in pursuing collegiate aviation programs are "different" from traditional college students. Aviation students are not searching for a career; they have found one and are taking steps to realize their dreams. They approach learning as an adult. They are motivated from within, see education as a means of solving problems that occur in the course of life, and learn better in discussion groups than in lectures. They see learning as a utility from which an application can be made. The implications of this study are that aviation educators should further explore and adopt adult-education learning strategies and methodologies.

\section{ADDITIONAL SUGGESTED RESEARCH}

Since the results of this study suggest that collegiate aviation students fit the adult learning model in most respects, future research should concentrate on discovering or developing teaching methodologies that consider these findings. The goal of future research should be to determine how the findings of the current study may be used to optimize learning for aviation students. 
Tim Brady holds a Ph.D. in Higher Education Administration from Saint Louis University, a Master of Science Degree from Abilene Christian University, and a Bachelor of Science Degree from Troy State University. He is currently the Dean of the School of Aviation at Embry-Riddle Aeronautical University in Daytona Beach, Florida. He also serves on the Board of Trustees of the Council on Aviation Accreditation and is the Chairman of its Accreditation Committee. He is dual rated as a pilot and návigator and holds the Air Transport Pilot (ATP) rating.

Alan J. Stolzer holds an M. S. in Aeronautical Science from Embry-Riddle Aeronautical University and a B. S. In Aerospace Science from the College of the Ozarks. He is an Associate Dean and a Professor of Aviation Science at Parks College of Engineering and Aviation, Saint Louis University.

Bradley Muller holds Ph.D. and Master of Science Degrees in Meteorology from Florida State University, and a Bachelor of Science Degree in Meteorology from San Jose State University. He is currently an Assistant Professor of Applied Aviation Sciences at Embry-Riddle Aeronautical University in Daytona Beach, Florida.

Debbie Schaum holds a Master of Arts Degree from Webster University and a Bachelor of Science Degree from University of Missouri. She is currently an Associate Professor in Applied Aviation Sciences at Embry-Riddle Aeronautical University. She also serves as Chairman for the University Scholarship Committee, is Program Coordinator for the Aeronautical Science Student Success Program and Faculty Advisor for the East Central Chapter of Women In Aviation International. 


\section{REFERENCES}

Beder, H., Beder C., \& Natalino (1988). The Effects of Andragogical Teacher Training on Adults Students= Attendance and Evaluation of Their Teachers. Adult Education Quarterly, 38 (2), 75-87.

Brady T. (1991, October). A Word for Aviation Educators. Presentation to the University Aviation Association Brady T. (2000). Pilot Education: The Beginnings. Journal of Aviation/Aerospace Education \& Research, 9 (2),

21-25.

Campbell, W.E. (1997). Introduction, In W.M. Campbell and K.A. Smith, New Paradigms for College Teaching, (pp. V-XIII, 281) Interaction Book Company, Edina, Minnesota.

Darkenwald, G. G. (1982). Factorial structure of differences in teaching behavior related to adult/pre-adult student age status. Adult Education, 32 (4), 197-204.

Davenport, J., \& Davenport, J. A. (1985). A chronology and analysis of the andragogy debate. Adult Education Quarterly, 35 (3), 152-159.

Delahaye, B. L., Limerick, D. C., \& Hearn, G. (1994). The relationship between andragogical and pedagogical orientations and the implications for adult learning.

Adult Education Quarterly, 44 (4), 187-200.

Elias, J. L. (1979). Andragogy revisited. Adult Education, 29, 252-255.

Green, M.F. (1998). Aviation instruction through flight simulation and related learning. Ph.D. Dissertation, Dissertation Abstracts International, 59-11 (Sec. A), 4029.

Grow. Gerald O., (1991). Teaching learners to be self directed, Adult Education Quarterly, 41 (3), 32 -134.

Hatcher, T., Hinton, B., \& Swartz, J. (1996). Graduate student's perceptions of university team-teaching. College Student Journal, 30 (3), 367-376.

Hawkins, R. M. F \& Kapelis, L. (1993). Teaching hypnosis: The andragogy and direct-teaching models. Australian Journal of Clinical \& Experimental Hypnosis, 21 (2), 37-43.

Kanske, C. A. (2001). Learning styles of pilots currently qualified in U.S. Air Force aircraft. Unpublished Journal of Air Transportation Worldwide manuscript (expected publication date, Fall 2001).

Knowles, M. S. (1977a). The Modern Practice of Adult Education-Andragogy versus Pedagogy,New York, Association Press.

Knowles, M. S. (1977b). Adult learning processes: Pedagogy and andragogy. Religious Education, 72 (2), $202-211$.

Knowles, M. S., (1979). The Adult Learner: A Neglected Species, Houston, Gulf Publishing Co.

Knowles, M. S. (1979). Andragogy revisited part II. Adult Education, 30, 52-53.

Knowles, M. S. (1980). The Modern Practice of Adult Education - From Pegagogy to Andragogy, New York, Association Press.

Knowles, M. S. and Associates (1984), Andragogy in Action, San Francisco, Jossey-Bass Publishers.

Lovell, R. B. (1980) Adult Learning, New York, John Wiley and Sons.

Marshak, R. J. (1983). What's between pedagogy and andragogy? Training \& Development Journal, 37 (10), 80 -

81.

McKenzie, L. L. (1977). The Issue of Andragogy. Adult Education, 27 (4), 225-229.

McKenzie, L. (1979). A response to Elias. Adult Education, 29, 256-260

Meyer, S. L. (1977). Andragogy and the aging adult learner. Educational Gerontology, 2 (2), 115-122.

Moore, P.J. \& Telfer, RA. (1990). Approaches to learning: relationships with pilot performance, The Journal of Aviation/Aerospace Education and Research, 1, (1), 44-58.

Ohliger, J. (1991). Social philosophy: Its past, present, and future, Adult Learning, 2, (8), 14 - 17.

Patterson, B. H. (1986). Creativity and andragogy: A boon for adult learners. Journal of Creative Behavior, 20 (2), 99-109.

Pratt, D.D. (1988). Andragogy as a relational construct, Adult Education Quarterly, 38 (3), 160-172.

Pratt, D.D. (1993). Andragogy after twenty-five years. In Sharan Merriam (Ed.), Adult Learning Theory: An Update. (pp. 15-25). San Francisco: Jossey-Bass, Publishers. 
Quilty, S.M. (1996). Cognitive learning bias of college students in an aviation program. Journal of Air Transportation World Wide, 1 (5).

Rachal, J. (1983). The andragogy-pedagogy debate: Another voice in the fray. Lifelong Learning: The Adult Years, $6(9), 14-15$.

Rachal, J.R. (1994) Andragogical and pedagogical methods compared: a review of the experimental literature. University of Southern Mississippi. ( ERIC document no. ED 380 566.)

Telfer, R. A. (1993). What makes aviation instruction different. In R. A. Telfer, Aviation Instruction and Training (pp 209-218). Aldershot, England: Ashgate Publishing Limited

Richardson D. \& Birge B. (1995). Teaching physiology by combined passive (pedagogical) and active (andragogical) methods, The American Journal of Physiology, 268, (6), S66(9).

Rosenthal, N. (1990). Active learning/empowered learning, Adult Learning, 1, (5), 16-19.

Tennant, M. (1985). An evaluation of Knowles' theory of adult learning, International Journal of Lifelong Education, 5 (2), 113-122.

Yonge, G. D. (1985). Andragogy and pedagogy: Two ways of accompaniment. Adult Education Quarterly, 35 (3), 160-167. 


\section{APPENDIX}

\section{SURVEY OF LEARNER CHARACTERISTICS}

\section{Section A. Demographics}

Check the appropriate box or fill in the answer.
1. Age:
$\square 16-19$
$\square 20-25$
$\square>25$

2. Sex: $\quad \square$ Female $\square$ Male

3. College or University: $\quad \square$ SLU $\quad \square$ FSU $\square$ ERAU

4. Year in school: $\square$ Freshman $\square$ Sophomore $\square$ Junior $\square$ Senior

5. My major is:

口Undeclared (or undecided)

$\square$ Aviation

$\square$ Other (please specify full name)

\section{Section B. Questionnaire}

Please mark the appropriate box for each question.

1. I have already determined my intended profession.

2. I see my education as a means to accumulate knowledge for the future more than as a means for being effective in solving current problems.

3. Others see me as self-directed.

4. I am attending college primarily because my parents want me to.

5. I see a clear connection between what I learn in my classes and my experience in day-to-day life day-to-day life.

6. I depend on others to motivate me to learn.

7. I learn better in classroom discussion groups than I do in classroom lectures.

Thanks for your cooperation. 